\title{
VALIDITY AND RELIABILITY OF THE LITHUANIAN VERSION OF PROSOCIAL TENDENCIES MEASURE - REVISED (PTMR)
}

\author{
Saulius Šukys $\mathbf{1}$, Edita Šukienè ${ }^{2}$ \\ Lithuanian Sports University', Kaunas, Lithuania \\ Kaunas Region Education Centre ${ }^{2}$, Kaunas, Lithuania
}

\begin{abstract}
Background. The study was carried out with the aim to examine the construct validity and reliability of a Prosocial Tendencies Measure-Revised (PTM-R) (Carlo, Hausmann, Christiansen, \& Randall, 2003).

Methods. The study process was done following four stages. In stage 1, 984 adolescents between ages of 13 to 16 years $(M$ age $=14.9, S D=0.97 ; 50.3 \%$ girls $)$ completed a translated version of the scale. In this stage Exploratory Factor Analyses (EFA) was carried out in order to measure the structure of the PTM-R. In stage 2, 757 adolescents between ages of 13 to 16 years $(M$ age $=14.24, S D=.81 ; 51.78 \%$ girls $)$ completed the questionnaire and Confirmatory Factor Analyses (CFA) was made. In stage 3, validity of the PTM-R was investigated. In stage 4, reliability of the measure was tested by evaluating Cronbach's alpha values.

Results. Exploratory Factor analysis of the PTM-R revealed four-factor solutions. A six-factor solution as in original measure was not obtained. Confirmatory factor analysis confirms four-factor structure of PTM-R and supports the multidimensional definition of prosocial behaviour. Three types of prosocial behaviour as anonymity, altruism, and public prosocial behaviour was the same as in the original measure. Other three types of prosocial behaviour emerged as one factor and were entitled as help in emergency. Correlation analyses between prosocial behaviour and different types of aggression showed good level of discriminant validity.

Coefficient alpha was used to estimate of reliability based on the internal consistency among items. Alpha coefficients were .85 for help in emergency, .71 for anonymous prosocial behaviour, .68 for altruistic behaviour, and .59 for public prosocial behaviour.

Conclusions. In conclusion, the four-factor structure of PTM-R was obtained. Results showed that the adapted measure was valid and reliable for Lithuanian adolescents aged between 13 and 16. Contradiction to the original measure structure and future research directions are discussed.
\end{abstract}

Keywords: prosocial behaviour, prosocial behaviour measure, validity and reliability.

\section{INTRODUCTION}

I

recent years, there has been an increase in social and psychological research on the various forms of youth aggression and their differential associations with social and psychological adjustment (Kamper \& Ostrov, 2013), social cognitive factors (Bradshaw, Goldweber, \& Garbarino, 2013) as well as other social and situational factors (Winstok, 2010). The problematic behaviour of adolescents in the school setting has been addressed with prominent interest by a number of scholars (Kokko, Tremblay, Lacourse, Nagin, \& Vitaro, 2006; SelahShayovits, 2014). It is not thus accidental that parents, teachers and other members of the society commonly believe that children first of all strive to satisfy their individual needs. It consequently determines their egoistic and selfish actions (Carlo, 2006). On the other hand, the formal standards and rules adopted by the society not always ensure prosocial behaviour (Carlo, Knight, McGinley, Zamboanga, 
\& Jarvis, 2010). Not surprisingly, in addition to the most recent studies of aggression, prosocial behaviour has also been investigated with the ever increasing interest.

Even though the causes of prosocial behaviour, especially those of altruism, have been extensively researched (e.g. see Kurzban, BurtonChellew, \& West, 2014), the number of such studies has increased during the recent years (Carlo et al., 2010; Hardy, Carlo, \& Roesch, 2010; Kumru, Carlo, Mestre, \& Samper, 2012). On the other hand, the interest in the prosocial behaviour of adolescents and other related qualities of a personality is of utmost importance when drafting efficient educational programs aimed at the prevention of antisocial and problematic risk-bearing behaviours or measuring moral behaviour relationship with pupils' involvement in different prosocial activities.

Prosocial behaviour is defined as any act that benefits another person or other persons (Aronson, Wilson, \& Akert, 2005). Analyses of such behaviour in sports setting is important as sports by nature is a social context in which participant interacts with, related to, and influence each other (Kavussanu, 2008). Moreover, sport has a unique social and educational environment, where, unlike other life contexts, moral decisions have to be made within a very short period of time under psychological pressure (Naylor \& Yeager, 2013). Not surprisingly researchers focus on prosocial and antisocial behaviour expression towards teammates and opponents (Boardley \& Kavussanu, 2010; Kavussanu \& Boardley, 2009), association of different sport context with athletes' prosocial and antisocial behaviours (Rutten et al., 2011), achievement goal orientation relationship with athletes' behaviour (Boadley \& Kavussanu, 2010), athletes' perceived motivational climate effects on prosocial and antisocial behaviours of hockey and netball players (Boardley \& Kavussanu, 2009), athletes' perception of social identity association with their prosocial and antisocial behaviours (Bruner, Boardley, \& Cote, 2014). On the other hand, these studies focused primarily on athletes' behaviour in sports settings. Recently, there has been only one study pubished analysing athletes' prosocial behaviour in different settings (Kavussanu, Boardley, Sagar, \& Ring, 2013).

Recent studies have shown that prosocial behaviour is a broad and multidimensional construct (Carlo \& Randall, 2002; Carlo et al., 2003; Carlo et al., 2010; Azimpour, Neasi, Shehni-Yailagh,
\& Arshadi, 2012). One of the instruments that measures different types of prosocial behaviour is Prosocial Tendencies Measure - Revised originally developed by Carlo, Hausmann, Christiansen, and Randall in 2003. This 21-item instrument measures six types of prosocial behaviour. Firstly this instrument was used with Lithuanian adolescents analysing links between pupils' participation in extracurricular activities and their prosocial behaviour (Šukys, 2010). Although the translation of the instrument was explained in this study, more information about its validity was not mentioned. Another study aimed at establishing relationship between 16-18-year-old students' participation in extracurricular activities and their prosocial behaviour as well as their value orientations (Baltakiene, 2013) applied the same instrument. In this study exploratory factor analyses revealed four factor structure but no additional analyses and explanation was made.

The need for new knowledge related to the evaluation of adolescents' prosocial behaviour in relation with their involvement in sport and physical education urges us to apply a valid research instrument to measure such behaviour. Based on the earlier studies that lack information about the validity of adapted Prosocial Tendencies Measure - Revised (PTM-R) the aim of this study was to validate adapted PTM-R with two independent samples.

\section{METHODS}

The first study (stage 1) was conducted to examine the structure of the measure using exploratory factor analysis (EFA) with one sample. In the second study (stage 2), factor structure was examined using Confirmatory factor analysis (CFA) with the second sample. In stage 3 , discriminant validity was tested evaluating the measures against each other. We examined whether prosocial behaviours were related or unrelated to another construct (aggressive behaviour). Finally, in stage 4, reliability of the measure was tested by evaluating Cronbach's alpha values.

Participants. The first sample of participants included 984 adolescents between ages of 13 to 16 years $(M$ age $=14.9, S D=0.97 ; 50.3 \%$ girls $)$. The participants were recruited from one district in the centre of Lithuania. The sample was drawn from schools representing the main schools, secondary schools and gymnasiums. In total, 16 schools and four different age groups (i.e. four classes) were 
randomly selected and included into the study. The second sample of participants involved 757 adolescents between ages of 13 to 16 years $(M$ age $=$ $14.24, S D=0.81 ; 51.78 \%$ girls). The participants were recruited from the same district of Lithuania.

Measures. Prosocial Tendencies Measure Revised (PTMR) proposed by Carlo, Hausmann, Christiansen, and Randall (2003) was adapted to Lithuanian respondents using backtranslation procedure described by Hambleton, Merenda, and Spielberger (2005). Participants completed the translated version of the Prosocial Tendencies MeasureRevised (PTMR) to access how likely they were to engage in prosocial behaviours across a variety of situations. Participants rated the extent to which statements described them using a 5point Likerttype scale (from 1 = does not describe me at all through to $5=$ describes me greatly). Original version of PTM-R assesses six types of prosocial behaviours: altruistic, public, emotional, dire, anonymous, and compliant.

Aiming at establishing validity participants of the second sample completed the Aggression Questionnaire (Buss \& Perry, 1992). This is a 29item instrument used to assess four components of aggressive behaviour: physical aggression, verbal aggression, anger, and hostility. The students had to assess each statement on a 5-point scale from 1 (extremely uncharacteristic of me) to 5 (extremely characteristic of me). This instrument earlier was validated with children (Dumčienè, Sipavičienè, Malinauskas, Klizas, \& Ramanauskienė, 2010), and adults (Čèsnienė \& Kašinska, 2011).

Procedure. Firstly the study was contacted with the school administration. After the permission was given from the appropriate administration bodies in schools, investigators arrived at the schools. Children with parental consent who also assented to participate were given questionnaire booklets during regular class hours within their normal classrooms. Questionnaires were administered by the investigator at the beginning of the class. Participants were informed about the purpose of the study, they were explained that all responses would be kept anonymous and confidential and used only for research purposes, that participation was voluntary, and that participants could withdraw at any time.

Data analysis. Descriptive statistics, Cronbach's alpha analyses on each of the subscales, correlational analyses and EFA were performed using IBM SPSS Statistics for Windows software (version 19.0). CFA analyses were performed using AMOS 18. CFA was performed to test factor structure retained from the EFA. A model with the four factor structure, based on EFA, was created and submitted for confirmation on the second sample. Chi-Squared test (values closer to zero indicate a better fit), root mean square error of approximation - RMSEA (a value of .06 or less is indicative of acceptable model fit) (Hu \& Bentler, 1999), comparative fit index - CFI which value $>.90$ indicate good model fit, value $>.95$ - very good model fit (Arbuckle, 2006).

\section{RESULTS}

Exploratory factor analysis using the principal components method of extraction and varimax rotation was performed on all 21 items. Four factors with eigenvalues $>1$ emerged, explaining $50.73 \%$ of the total variance (Kaiser Meyer Oldkin $=.88$, Bartlett's test of sphericity yielded $\chi^{2}=6457.80$, $d f=210, p<.001)$. The first factor was defined by 10 items containing three types of prosocial behaviour (dire, compliant and emotional), and explained $25 \%$ of the variance. This factor was referred to as Help in emergency. The second factor (anonymous prosocial behaviour) was defined by four items and explained $14 \%$ of the variance. The third factor (altruism) was defined by four items and explained $10 \%$ of the variance, whereas the fourth factor (public prosocial behaviour) consisted of three items, and accounted for $8 \%$ of the variance.

As a six-factor solution was not obtained, the four-factor structure identified in EFA was examined using CFA in the second sample. The model had a good fit $\chi 2=(164)=569.039$, $p<.001, C F I=.907$, RMSEA $=.053$ [ .047- .058]. This confirms the four-factor structure of PTM-R and supports the multidimensional definition of prosocial behaviour (Table 1).

Next correlations among the four types of prosocial behaviour were examined (Table 2). As the table shows, correlations ranged from .32 to .39 indicating that all subscales related with one construct. Additionally validity was examined by computing the correlations between prosocial behaviours and aggression (Table 2). Help in emergency, anonymous and public prosocial behaviour correlation with the different types of aggression were small or not significant. Negative correlation was observed between altruistic behaviour and aggression types. 
Table 1. Factor loadings for exploratory factor analysis with varimax rotation and confirmatory factor analysis

Note. The type of prosocial behaviour which is reflected by an item in the original measure is given in parentheses.

\begin{tabular}{|c|c|c|}
\hline Scale & $\begin{array}{c}\text { Study } 1 \\
\text { EFA }\end{array}$ & $\begin{array}{c}\text { Study } 2 \\
\text { CFA }\end{array}$ \\
\hline \multicolumn{3}{|l|}{ Help in emergency } \\
\hline Item 5 (Dire) & .78 & .65 \\
\hline Item 6 (Compliant) & .76 & .64 \\
\hline Item 21 (Emotional) & .75 & .63 \\
\hline Item 16 (Compliant) & .74 & .59 \\
\hline Item 11 (Emotional) & .72 & .46 \\
\hline Item 13 (Dire) & .67 & .61 \\
\hline Item 19 (Emotional) & .67 & .73 \\
\hline Item 8 (Dire) & .66 & .60 \\
\hline Item 2 (Emotional) & .62 & .61 \\
\hline Item 15 (Emotional) & .59 & .72 \\
\hline \multicolumn{3}{|l|}{ Anonymous } \\
\hline Item 14 & .76 & .77 \\
\hline Item 10 & .73 & .66 \\
\hline Item 17 & .72 & .62 \\
\hline Item 7 & .61 & .45 \\
\hline \multicolumn{3}{|l|}{ Altruism } \\
\hline Item 18 & .75 & .72 \\
\hline Item 20 & .68 & .46 \\
\hline Item 9 & .62 & .52 \\
\hline Item 4 & .42 & .54 \\
\hline \multicolumn{3}{|l|}{ Public } \\
\hline Item 3 & .76 & .62 \\
\hline Item 1 & .74 & .47 \\
\hline Item 12 & .33 & .59 \\
\hline
\end{tabular}

Table 2. Descriptive statistics, alpha coefficients, and subscale correlations $(\boldsymbol{n}=757)$

\begin{tabular}{|c|c|c|c|c|c|c|c|c|}
\hline Variable & 1 & 2 & 3 & 4 & 5 & 6 & 7 & 8 \\
\hline \multicolumn{9}{|l|}{ 1. Help in emergency } \\
\hline 2. Anonymous & $.33 * *$ & & & & & & & \\
\hline 3. Public & $.36^{* *}$ & $.33 * *$ & & & & & & \\
\hline 4. Altruistic & $-.32 * *$ & $-.34 * *$ & $-.39 * *$ & & & & & \\
\hline 5. Physical Aggression & .03 & $.13^{*}$ & $.14^{* *}$ & $-.28 * *$ & & & & \\
\hline 6. Verbal Aggression & $.20 *$ & $.15^{* *}$ & $.13 * *$ & $-.20 * *$ & $.47 * *$ & & & \\
\hline 7. Anger & $.13 * *$ & .09 & $.10^{*}$ & $-.15 * *$ & $.58 * *$ & $.56^{* *}$ & & \\
\hline 8. Hostility & $.17^{* *}$ & $.19 * *$ & $.16^{*}$ & $-.22 * *$ & $.39 * *$ & $.45^{* *}$ & $.48 * *$ & \\
\hline Mean & 3.31 & 2.24 & 2.41 & 3.51 & 2.75 & 2.89 & 2.69 & 2.68 \\
\hline Standard deviation & 0.80 & 0.90 & 0.83 & 0.87 & 0.77 & 0.79 & 0.75 & 0.69 \\
\hline Cronbach alpha & .85 & .71 & .59 & .68 & .73 & .69 & .72 & .71 \\
\hline
\end{tabular}

Note. $* * p<.01$. 
Coefficient alpha was used to estimate the reliability based on the internal consistency among items. Alpha coefficients were .85 for help in emergency, .71 for anonymous prosocial behaviour, .68 for altruistic behaviour, and .59 for public prosocial behaviour.

\section{DISCUSSION}

The study aimed to validate adapted Prosocial Tendencies Measure-R for Lithuanian adolescents aged between 13 and 16. For this reason, exploratory factor analysis and confirmatory factor analysis were done. Discriminant validity and reliability were measured. One of the main findings of this study was the validation of a fourfactor model of prosocial behaviour. Although such types of prosocial behaviour as dire, emotional and compliant constitute a single form of prosocial behaviour, yet this proves that prosocial behaviour is a multidimensional construct (Carlo \& Randall, 2002; Carlo et al., 2010). When commenting upon the four-factor model, attention should be paid to several factors. In previous research, the scores of these three types of prosocial behaviour were the highest (except for altruism), and they correlated far more prominently (Carlo et al., 2003). Meanwhile, public, anonymity and altruism factors are singled as separate forms, and the results corroborate the data obtained by other researchers (Carlo \& Randall, 2002; Carlo et al., 2010). The cultural factor should also be considered. Other studies suggest the existence of differences while comparing prosocial behaviour in adolescents of different cultures (Kumru et al., 2012) as the behaviour of adolescents is determined by their cultural values (Brittian et al., 2013).

The prosocial behaviour of adolescents is affected by the behaviour of their parents such as parent-child connectedness (Hana, Xin, \& Randall, 2013) and parental monitoring, especially for such types of prosocial behaviour as emotional, dire and compliant (Carlo et al., 2010). Cultural differences in parenting practices have been proven to exist (Yagmurlu \& Sanson, 2009). Even though the most up-to-date researches adapting the scale of prosocial behaviour in other cultures (in this particular case, in Iran) confirmed the existence of six types of prosocial behaviour (Azimpour et al., 2012); however, no data has been found on previous adaptations of this scale in Eastern or Central European countries.

Some authors suggest that the reliability level is acceptable at .80 , and the value of .60 to .69 is minimally reliable (Cohen, Manion, \& Morrison, 2009) although the value of reliability for one of the subscales was lower than minimum cut-off value. Nevertheless the reliability of the subscales is appropriate as in other studies it ranged from .59 to .86 in younger adolescents and from .75 to .86 in middle-aged adolescents (Carlo et al., 2003). In other studies with Lithuanian adolescents aged 16-18 years, alpha values ranged from .55 to .86 (Baltakiene, 2013). The low value of alpha may be justified if the number of items in the scale is relatively low (Schmitt, 1996). This may explain low alpha value for public prosocial behaviour as it was defined by three items.

\section{CONCLUSION}

In conclusion, the four factor structure of PTM-R was obtained. Results showed that the adapted measure was valid and reliable for Lithuanian adolescents aged between 13 and 16 . This measure could be used while analysing peculiarities of adolescent prosocial behaviour and also behaviour relationship with their involvement in sports activities and other extracurricular activities. This measure also could be used by assessing effectiveness of the educational programmes for improvement of adolescents' moral behaviour specifically in sport settings or generally on school. By applying this instrument we recommend that researchers should carefully consider which type of prosocial behaviour is of the greatest interest in their studies. As different subscales reflect different types of prosocial behaviour we do not recommend calculating only the total value of measurement.

As this study was aimed at validation of adapted PTM-R to Lithuanians, further research is needed focusing on the reliability applying other methods of estimation, for example test-retest measure. Additionally, studies focusing on other types of validity measure are encouraged. 


\section{REFERENCES}

Arbuckle, J. L. (2006). AMOS user's guide 7.0. Spring House, PA: AMOS Development Corporation.

Aronson, E., Wilson, T. D., \& Akert, R. M. (2005). Social psychology (5th ed.). Upper Saddle River, NJ: Pearson Education.

Azimpour, A., Neasi, A., Shehni-Yailagh, M., \& Arshadi, N. (2012). Validation of "Prosocial tendencies measure" in Iranian university students. Journal of Life Science and Biomedicine, 2(2), 34-42.

Baltakienè, L. (2013). Relationship between 16-18-yearold students' participation in extracurricular activities and their pro-social behaviour as well as heir value orientations. Education. Physical Training. Sport, 1(88), 18-24.

Boardley, I. D., \& Kavussanu, M. (2009). The influence of social variables and moral disengagement on prosocial and antisocial behaviours in field hockey and netball. Journal of Sports Sciences, 27, 843-854. doi:10.1080/02640410902887283

Boardley, I. D., \& Kavussanu, M. (2010). Effects of goal orientation and perceived value of toughness on antisocial behavior in soccer: The mediating role of moral disengagement. Journal of Sport \& Exercise Psychology, 32(2), 176-192.

Bradshaw, C. P., Goldweber, A., \& Garbarino, J. (2013). Linking socialenvironmental risk factors with aggression in suburban adolescents: The role of socialcognitive mediators. Psychology in the Schools, 50(5), 433-450. doi: $10.1002 /$ pits. 21690

Brittian, A. S., O‘Donnell, M., Knight, G. P., Carlo, G., UmanaTaylor, A. J., \& Roosa, M. W. (2013). Associations between adolescents' perceived discrimination and prosocial tendencies: The mediating role of Mexican American Values. Journal of Youth and Adolescence, 42(3), 328-341. doi:10.1007/s10964-012-9856-6

Bruner, M. W., Boardley, I. D., \& Cote, J. (2014). Social identity and prosocial and antisocial behaviour in youth sport. Psychology of Sport and Exercise, 15, 56-64. doi: 10.1016/j.psychsport.2013.09.003.

Buss, A. H., \& Perry, M. P. (1992). The aggression questionnaire. Journal of Personality and Social Psychology, 63, 452-459.

Carlo, G., Hausmann, A., Christiansen, S., \& Randall, A. (2003). Sociocognitive and behavior correlates of a measure of prosocial tendencies for adolescents. Journal of Early Adolescence, 23, 107-134. doi:10.1177/0272431602239132

Carlo, G. (2006). Care-based and altruistically-based morality. In M. Killen \& J. G. Smetana (Eds.), Handbook of moral development (pp. 551-579). Mahwah, NJ: Lawrence Erlbaum Associates.

Carlo, G., Knight, G. P., McGinley, M., Zamboanga, B. L., \& Jarvis, L. (2010). The multidimensionality of prosocial behaviors and evidence of measurement equivalence in Mexican American and European American early adolescents. Journal of Research on Adolescence, 20(2), 334-358. doi:10.1111/j.1532-7795.2010.00637.x

Carlo, G., \& Randall, B. A. (2002). The development of a measure of prosocial behaviors for late adolescents. Journal of Youth and Adolescence, 31, 31-41.

Čèsnienè, J., \& Kašinska, A. (2011). Agresyvus vairavimas: vairuotoju agresyvumo, pykčio ir saviveiksmingumo sąsajos. Psichologija, 43, 63-77 (Abstract in English).

Cohen, L., Manion, L, \& Morrison, K. (2009). Research methods in education ( $6^{\text {th }}$ ed.). London: Routledge.

Dumčienė, A., Sipavičienė, S., Malinauskas, R., Klizas, \& Ramanauskienè, I. (2011). Paaugliu agresyvaus elgesio sąsajos su fiziniu aktyvumu. Sveikatos mokslai, 19, 2718-2721 (Abstract in English).

Hambleton, R. K., Merenda, P., \& Spielberger, C. (Eds.). (2005). Adapting educational and psychological tests for cross-cultural assessment. Hillsdale, NJ: Lawrence S. Erlbaum Publishers.

Hana, Y., Xin, F., \& Randall, D. (2013). Adolescents“ empathy and prosocial behavior in the family context: A longitudinal study. Journal of Youth and Adolescence, 42(12), 1858-1872. doi:10.1007/s10964-012-9900-6

Hardy, S. A., Carlo, G., \& Roesch, S. C. (2010). Links between adolescents' expected parental reactions and prosocial behavioral tendencies: The mediating role of prosocial values. Journal of Youth and Adolescence, 39(1), 84-95. doi:10.1007/s10964-008-9383-7

Hu, L., \& Bentler, P. M. (1999). Cut-off criteria for fit indexes in covariance structure analysis: Conventional criteria versus new alternatives. Structural Equation Modelling, 6(1), 1-55.

Kamper, K. E., \& Ostrov, J. M. (2013). Relational aggression in middle childhood predicting adolescent socialpsychological adjustment: The role of friendship quality. Journal of Clinical Child \& Adolescent Psychology, 42(6), 855-862. doi:10.1080/15374416.20 13.844595

Kavussanu, M., Boardley, I. D., Sagarm S. S., \& Ring, Ch. (2013). Bracketed morality revisited: How do athletes behave in two contexts? Journal of Sport \& Exercise Psychology, 35, 44-463.

Kavussanu, M., \& Boardley, I. D. (2009). The prosocial and antisocial behavior in sport scale. Journal of Sport \& Exercise Psychology, 31, 97-117.

Kavussanu, M. (2008). Moral behaviour in sport: A critical review of the literature. International Review of Sport and Exercise Psychology, 1(2), 124-138.

Kokko, K., Tremblay, R. E., Lacourse, E., Nagin, D. S., \& Vitaro, F. (2006). Trajectories of prosocial behavior and physical aggression in middle childhood: Links to adolescent school dropout and physical violence. 
Journal of Research on Adolescence, 16(3), 403-428. doi:10.1111/j.1532-7795.2006.00500.x

Kumru, A., Carlo, G., Mestre, M.V., \& Samper, P. (2012). Prosocial moral reasoning and prosocial behavior among Turkish and Spanish adolescents. Social Behavior and Personality, 40(2), 205-214. doi:10.2224/ sbp.2012.40.2.205

Kurzban, R., BurtonChellew, M. N., \& West, S. A. (2014). The evolution of altruism in human. Annual Review of Psychology, 66, 575-599. doi:10.1146/ annurev-psych-010814-015355

Naylor, A. H., \& Yeager, J. M. (2013). A 21st-century framework for character formation in sports. Peabody Journal of Education, 88, 212-224. doi:10.1080/01619 56X.2013.775878

Rutten, E. a., Schuengel, C., Dirks, E., Stams, G. J. J. M., Biesta, G. J. J., \& Hoeksma, J. B. (2011). Predictors of antisocial and prosocial behavior in an adolescent sports context. Social Development, 20, 294-315. doi:10.1111 /j.1467-9507.2010.00598.
Schmitt, N. (1996). Uses and abuses of coefficient alpha. Psychological Assessment, 8, 350-353.

Šukys, S. (2010). Dalyvavimo opamokinèje veikloje sąsajos su mokinių prosocialaus elgesio raiška. Ugdymas. Küno kultüra. Sportas, 4(79), 77-85.

SelahShayovits, R. (2014). School for aggression: Types of adolescent aggression in school student and school dropouts. International Journal of Adolescence and Youth, 11(4), 303-316. doi:10.1080/02673843.2004.97 47937

Yagmurlu, B., \& Sanson, A. (2009). Parenting and temperament as predictors of prosocial behaviour in Australian and Turkish Australian. Australian Journal of Psychology, 61(2), 77-88. doi:10.1080/00049530802001338

Winstok, Z. (2010). The effect of social and situational factors on the intended response to aggression among adolescents. The Journal of Social Psychology, 150(1), 57-76. doi:10.1080/00224540903232290

Corresponding author Saulius Šukys Lithuanian Sports University Sporto str. 6, LT-44221 Kaunas Lithuania

Tel. +370 37302657

E-mail saulius.sukys@1su.lt 